\title{
Role of exhaled nitric oxide as a predictor of atopy
}

\author{
Karina M Romero ${ }^{1,2}$, Colin L Robinson ${ }^{1}$, Lauren M Baumann ${ }^{1}$, Robert H Gilman ${ }^{1,2,3}$, Robert G Hamilton ${ }^{4}$, \\ Nadia N Hansel ${ }^{5}$, William Checkley ${ }^{2,3,5^{*}}$ and PURA Study Investigators
}

\begin{abstract}
Background: The fractional exhaled nitric oxide (FeNO) is a quantitative, noninvasive and safe measure of airways inflammation that may complement the assessment of asthma. Elevations of FeNO have recently been found to correlate with allergic sensitization. Therefore, FeNO may be a useful predictor of atopy in the general population. We sought to determine the diagnostic accuracy of FeNO in predicting atopy in a population-based study.

Methods: We conducted a cross-sectional study in an age- and sex- stratified random sample of 13 to 15 year-olds in two communities in Peru. We asked participants about asthma symptoms, environmental exposures and sociodemographics, and underwent spirometry, assessment of FeNO and an allergy skin test. We used multivariable logistic regression to model the odds of atopy as a function of FeNO, and calculated area-under-the-curves (AUC) to determine the diagnostic accuracy of FeNO as a predictor of atopy.

Results: Of 1441 recruited participants, 1119 (83\%) completed all evaluations. Mean FeNO was 17.6 ppb (SD=0.6) in atopics and $11.6 \mathrm{ppb}(\mathrm{SD}=0.8)$ in non-atopics $(\mathrm{p}<0.001)$. In multivariable analyses, a FeNO>20 ppb was associated with an increase in the odds of atopy in non-asthmatics (OR=5.3, 95\% Cl 3.3 to 8.5) and asthmatics (OR=16.2, 95\% Cl 3.4 to 77.5). A FeNO>20 ppb was the best predictor for atopy with an AUC of 68\% (95\% Cl 64\% to 69\%). Stratified by asthma, the AUC was 65\% (95\% Cl 61\% to 69\%) in non-asthmatics and 82\% (95\% Cl 71\% to 91\%) in asthmatics.
\end{abstract}

Conclusions: FeNO had limited accuracy to identify atopy among the general population; however, it may be a useful indicator of atopic phenotype among asthmatics.

Keywords: Allergic sensitization, Asthma, Exhaled nitric, Allergic rhinitis

\section{Background}

The fractional exhaled nitric oxide (FeNO) is a noninvasive and sensitive biomarker of ongoing eosinophilic airway inflammation $[1,2]$. FeNO may be a useful marker in the assessment of asthma status and control [3,4]. It has shown potential promise as a non-invasive biomarker for asthma because it is a simple, well tolerated test with no risk to the participant [5] and it provides real-time, reproducible results in children aged $\geq 4$ years [1-3,6-9]. For these reasons, FeNO has been recently recommended as a clinical endpoint for the charac-

\footnotetext{
* Correspondence: wcheckl1@jhmi.edu

${ }^{5}$ Division of Pulmonary and Critical Care, School of Medicine, Johns Hopkins University, 1800 Orleans Street, Suite 9121, Baltimore MD 21205, USA

Full list of author information is available at the end of the article
}

terization of study populations, in clinical trials and observational studies [10]. Recent studies, however, have reported high levels of FeNO even in well-controlled asthma $[1,6,11]$, indicating that other factors may play a role in the determination of FeNO levels [12-15]. One potential factor that could explain variability in FeNO levels is atopic status.

Atopy is a clinical definition for an IgE-antibody responder, i.e., a personal tendency to become sensitized and produce IgE antibodies in response to allergens. Atopic individuals have an increased risk of developing asthma and other allergic diseases [16]. The definition of atopy, however, should only be considered when there is reported sensitization to allergen-specific IgE antibodies in serum or with a positive skin prick test to a specific allergen [16]. Recent studies have reported a strong 
association between FeNO and atopy [1,7,16,17]. Scott et al. [18] reported a positive correlation between FeNO and the number of positive skin prick tests in a cohort of asthmatics. Previous studies have also correlated aeroallergen sensitization with FeNO levels in atopic children $[7,13,16,19,20]$. These findings underscore the relevance of evaluating allergen sensitization status when FeNO is used as a biomarker in the diagnosis and monitoring of asthma [18]. More importantly, it also supports the hypothesis that FeNO may serve as a biomarker of atopy. The fact that atopy cannot always be identified using an allergy skin test [21], and the underlying risks involved in the determination of allergic skin sensitization increases the importance of studying the validity of FeNO as a simple, non-invasive biomarker for atopy $[2,4,17]$.

The presence of a low to normal FeNO level in patients with chronic respiratory symptoms could also be helpful to rule out atopic status $[20,22]$, however, there is a lack of strong evidence to support the role of FeNO in identifying atopy [2,5,11,23-25]. One recent study by Yao et al. reported that FeNO was a better marker of allergic sensitization than it was of asthma [17]. In this study, we seek to determine the clinical utility of FeNO as a noninvasive marker of atopy in a population-based study.

\section{Methods}

\section{Study design}

The study design is described in detail elsewhere [26]. We conducted a cross-sectional study of asthma prevalence in two regions in Peru. In December 2008, we selected a random sample of children aged 13 to 15 years from community censuses and visited them for enrollment into the study between April 2009 and December 2010. We asked participants about asthma and allergy symptoms, sociodemographics and environmental exposures, obtained anthropometry and a blood sample, and conducted an allergy skin test, a FeNO test and spirometry before and after bronchodilators. We used a previously validated Spanish version of the ISAAC questionnaire [13]. This study was approved by the Institutional Review Boards of the Johns Hopkins Bloomberg School of Public Health (Baltimore, USA) and A.B. PRISMA (Lima, Peru).

\section{FeNO assessment}

We measured FeNO using a portable chemiluminescence analyzer (NIOXMINO, Aerocrine, Solna, Sweden) according to joint ERS/ATS recommendations [4,25]. No assessments were made if a participant reported a respiratory infection in the last 2 weeks or if the participant was on oral corticosteroids. We categorized FeNO levels using cut-off values of $<20 \mathrm{ppb}, 20-35 \mathrm{ppb}$ and $>35$ $\mathrm{ppb}$, respectively [25].

\section{Assessment of atopy}

Allergy skin tests were performed using the Multi-Test II system (Lincoln Diagnostics, Decatur, IL) with allergen extracts made by ALK-Abello (Round Rock, TX). We used 10 allergens in the assessment: cockroach (Blattella germanica), dust mite mix (Dermatophagoides farinae and D. pteronyssinus), cat hair, dog epithelium, mouse epithelium, and mixed molds (Alternaria, Cladosporium, mixed Aspergillus, and mixed Penicillium). We also applied a histamine solution $(10 \mathrm{mg} / \mathrm{ml})$ as a positive control and saline $(0.9 \%)$ as a negative control. As per manufacturer's instructions, we recorded vertical and horizontal measurements of induration and erythema, alongside 0-2 scales of itchiness and pseudopodia 20 minutes after application. Atopy was defined as a positive skin response to any of the allergen specificities as previously described $[16,20,26]$.

\section{Definitions}

We defined current asthma symptoms as wheeze or use of asthma medications in the past 12 months; allergic rhinitis as nasal symptoms (i.e., rhinorrhea, nasal discharge, nasal obstruction or nasal-ocular pruritus) without cold or flu symptoms in the past 12 months; and, smoking as self-reported tobacco use. We defined allergic symptoms if a child had either asthma symptoms or allergic rhinitis in the past 12 months. We calculated body mass index (BMI) percentile according to World Health Organization reference values [27]. We classified underweight as $<5^{\text {th }}$ percentile; normal as $5^{\text {th }}$ to $84^{\text {th }}$ percentiles; overweight as $85^{\text {th }}$ to $94^{\text {th }}$ percentiles, and obese as $\geq 95^{\text {th }}$ percentile for their age and sex. We defined current inhaled corticosteroid use if the child used it in the last week.

\section{Biostatistical methods}

We compared continuous variables between two subgroups with t-tests if normally distributed and with Wilcoxon rank-sum tests if not normally distributed, and compared dichotomous or categorical values between two subgroups with chi-square tests. We used multiple linear regression to identify risk factors associated with logtransformed FeNO in our study population. We used multiple logistic regression to estimate the odds of atopy for FeNO first as a continuous variable and then as a categorical variable using the above defined cut-offs, adjusted for sex, allergy symptoms, BMI, personal history of tobacco use, secondhand smoke, seasonality and site. We excluded current use of inhaled corticosteroids as a covariate because only 2 participants reported such intake. To assess the diagnostic accuracy of FeNO to predict atopy, we constructed receiver-operating-characteristic (ROC) curves and calculated the areas-under-the-curve (AUC) using five-fold cross validation [28]. We also conduced 
Table 1 Study Characteristics

\begin{tabular}{llll}
\hline Variable & Children with FeNO and atopy data & Children with incomplete data & P \\
\hline Sample size & 1199 & 242 & $52 \%(125)$ \\
\hline Male, \% (n) & $52 \%(622)$ & $14.8(13.3-16.5)$ & 0.95 \\
\hline Age, mean (range) & $14.9(12.2-16.6)$ & $156.9(7.4)$ & 0.43 \\
\hline Height in cm, mean (SD) & $158.5(8.2)$ & $7.0 \%(17)$ & 0.05 \\
\hline Current Asthma, \% (n) & $7 \%(89)$ & $21 \%(51)$ & 0.83 \\
\hline Allergic rhinitis, \% (n) & $17 \%(201)$ & $38 \%(91)$ & 0.11 \\
\hline Rural, \% (n) & $52 \%(625)$ & $21.8(15.1-36.6)$ & 0.001 \\
\hline BMl, mean (range) & $21.1(13.9-39.2)$ & $19 \%(46)$ & 0.06 \\
\hline Secondhand smoke, \% (n) & $19 \%(232)$ & $4 \%(4)$ & 0.91 \\
\hline History of tobacco use, \% (n) & $5 \%(54)$ & & 0.59 \\
\hline
\end{tabular}

Table 2 Single variable and multivariable analyses of factors associated with Fractional exhaled nitric oxide (FeNO)

\begin{tabular}{|c|c|c|c|c|c|}
\hline \multicolumn{6}{|c|}{ Fractional exhaled nitric oxide in ppb } \\
\hline & $\mathrm{n}$ & Geometric mean (SD) & $P$ & Coefficient in log ppb & $\mathrm{P}$ \\
\hline \multicolumn{6}{|l|}{ Sex } \\
\hline Male & 622 & $15.8(0.7)$ & \multirow[t]{2}{*}{$<0.001$} & Reference & \\
\hline Female & 577 & $12.4(0.7)$ & & -0.22 & $<0.001$ \\
\hline \multicolumn{6}{|l|}{ Atopy } \\
\hline Yes & 556 & $17.6(0.6)$ & \multirow[t]{2}{*}{$<0.001$} & 0.36 & $<0.001$ \\
\hline No & 643 & $11.6(0.8)$ & & Reference & \\
\hline \multicolumn{6}{|l|}{ Current asthma } \\
\hline Yes & 89 & $27.9(1.0)$ & \multirow[t]{2}{*}{$<0.001$} & 0.48 & $<0.001$ \\
\hline No & 1110 & $13.3(0.7)$ & & Reference & \\
\hline \multicolumn{6}{|l|}{ Allergic Rhinitis } \\
\hline Yes & 201 & $21.8(0.9)$ & \multirow[t]{2}{*}{$<0.001$} & 0.31 & $<0.001$ \\
\hline No & 998 & $12.8(0.7)$ & & Reference & \\
\hline \multicolumn{6}{|c|}{ Season of FeNO measurement } \\
\hline Fall & 236 & $18.9(21.6)$ & \multirow[t]{4}{*}{$<0.01$} & Reference & \\
\hline Winter & 424 & $19.1(22.9)$ & & 0.11 & 0.07 \\
\hline Spring & 451 & $20.0(23.3)$ & & 0.20 & $<0.001$ \\
\hline Summer & 88 & $23.1(20.9)$ & & 0.23 & 0.01 \\
\hline \multicolumn{6}{|l|}{ Site } \\
\hline Lima & 574 & $15.6(0.8)$ & \multirow[t]{2}{*}{$<0.001$} & Reference & \\
\hline Tumbes & 625 & $12.4(0.7)$ & & -0.01 & 0.74 \\
\hline \multicolumn{6}{|c|}{ Personal history of tobacco smoke } \\
\hline Yes & 54 & $18.1(0.8)$ & \multirow[t]{2}{*}{$<0.01$} & & \\
\hline No & 1086 & $14.1(0.7)$ & & 0.12 & 0.20 \\
\hline \multicolumn{6}{|c|}{ Body mass index $\left(\mathrm{kg} / \mathrm{m}^{2}\right)$} \\
\hline Low weight & 18 & $17.2(15.9)$ & \multirow[t]{4}{*}{0.15} & Reference & \\
\hline Normal & 936 & $18.9(21.1)$ & & 0.01 & 0.93 \\
\hline Overweight & 212 & $22.9(23.2)$ & & 0.14 & 0.48 \\
\hline Obese & 33 & $22.8(28.7)$ & & 0.04 & 0.80 \\
\hline \multicolumn{6}{|l|}{ Second hand smoke } \\
\hline Yes & 232 & $14.3(0.7)$ & \multirow[t]{2}{*}{0.11} & -0.07 & 0.20 \\
\hline No & 967 & $13.1(0.8)$ & & Reference & \\
\hline
\end{tabular}


Table 3 Multivariable analyses of predictors of atopy in 1199 Peruvian children

\begin{tabular}{|c|c|c|c|c|}
\hline Variable & Crude Odds ratio & p-value & Adjusted Odds Ratio (95\% Cl) & p-value \\
\hline \multicolumn{5}{|c|}{ Fractional exhaled nitric oxide } \\
\hline$>35 \mathrm{ppb}$ & 6.7 & $<0.001$ & $5.6(3.7-8.8)$ & $<0.001$ \\
\hline 20-35 ppb & 2.5 & $<0.001$ & $2.2(1.5-3.2)$ & $<0.001$ \\
\hline$<20 \mathrm{ppb}$ & 1.0 & & Reference & \\
\hline Site (rural) & 0.5 & $<0.001$ & $0.4(0.3-0.6)$ & $<0.001$ \\
\hline \multicolumn{5}{|c|}{ Season of Fractional exhaled nitric oxide measurement } \\
\hline Fall & 1.0 & & Reference & \\
\hline Winter & 0.5 & $<0.001$ & $0.3(0.2-0.5)$ & $<0.001$ \\
\hline Spring & 0.4 & $<0.001$ & $0.2(0.2-0.4)$ & $<0.001$ \\
\hline Summer & 1.1 & 0.861 & $0.4(0.3-0.8)$ & $<0.001$ \\
\hline Allergy Symptoms & 2.3 & $<0.001$ & $1.5(1.1-2.0)$ & 0.03 \\
\hline Body mass index & 1.1 & 0.01 & $1.0(1.0-1.1)$ & 0.27 \\
\hline Personal smoke & 1.5 & 0.17 & $1.1(0.6-2.0)$ & 0.82 \\
\hline Second hand smoke & 1.1 & 0.62 & $1.1(0.8-1.6)$ & 0.41 \\
\hline
\end{tabular}

stratified analyses by asthmatic and rhinitis status. We conducted statistical analyses in STATA 11 (STATA Corp., College Station, USA).

\section{Results}

\section{Characteristics of the study population}

Of 1441 enrolled participants, 1199 (83\%) completed both FeNO and allergy skin test assessments. We did not observe major differences between those with and without incomplete assessments (Table 1); however, we were more successful in obtaining both FeNO and an allergy skin tests among participants in Tumbes vs. Lima $(\mathrm{p}<0.001)$. Of the 1199 children with complete measurements, $52 \%$ were male, mean age was 14.9 years $(\mathrm{SD}=0.9), 21 \%$ were overweight, the prevalence of atopy was $46 \%$ based on skin test results and mean FeNO was $19.7 \mathrm{ppb}(\mathrm{SD}=22.6)$.

\section{Factors associated with FeNO}

Boys had higher FeNO levels than girls (15.8 ppb vs. $12.4 \mathrm{ppb} ; \mathrm{p}<0.001)$. Children in Lima had higher FeNO levels than those in Tumbes (15.6 vs. 12.8 ppb; $\mathrm{p}<0.001)$. Mean FeNO was higher in atopics than in non-atopics (17.6 ppb vs. $11.6 \mathrm{ppb}$; $<0.001$ ), higher in asthmatics than in non-asthmatics (27.9 ppb vs. $13.3 \mathrm{ppb} ; \mathrm{p}<0.001)$ and higher in participants with allergic rhinitis compared to those without (21.8 ppb vs. 12.8 ; ppb p<0.001). FeNO also varied with season and personal history of tobacco use (all $\mathrm{p}<0.01$ ). We did not find statistically significant differences in FeNO levels with tobacco smoke exposure, either personal or secondhand smoke or BMI categories (Table 2). In multiple linear regression with log FeNO as the outcome, important associations remained with atopy, current asthma symptoms, rhinitis and sex $(\mathrm{p}<0.001)$.

\section{Predictors of atopy}

In multivariable logistic regression, the odds of atopy increased with higher FeNO levels and with allergic symptoms, and was lower among children living in Tumbes vs. Lima (Table 3). We identified a dose-response relationship between FeNO and atopy $(\mathrm{p}<0.001)$. Having a FeNO $>35$ ppb was associated with atopy in children after adjusting for sex, height, BMI, site, allergy symptoms, personal history of tobacco, second hand smoke exposure and season of FeNO measurement (adjusted OR=5.6, 95\% CI 3.6 to $8.8 ; \mathrm{p}<0.001$ ). FeNO levels $20-35 \mathrm{ppb}$ were also associated with an increased odds of atopy (adjusted $\mathrm{OR}=2.2,95 \%$ CI 1.5 to $3.1, \mathrm{p}<0.001)$.

Table 4 Diagnostic accuracy of Fractional exhaled nitric oxide (FeNO) for atopy

\begin{tabular}{|c|c|c|c|c|c|}
\hline & Sensitivity \% & Specificity \% & PPV \% & NPV \% & AUC\% $(95 \% \mathrm{Cl})$ \\
\hline FeNO > $20 \mathrm{ppb}$ & 47.8 & 81.5 & 69.1 & 64.4 & $68(64-69)$ \\
\hline FeNO > $25 \mathrm{ppb}$ & 52.2 & 71.7 & 61.4 & 63.4 & $67(64-70)$ \\
\hline FeNO $>35 \mathrm{ppb}$ & 47.1 & 74.7 & 61.7 & 62.0 & $66(63-69)$ \\
\hline \multicolumn{6}{|c|}{ By asthma status (FeNO > $20 \mathrm{ppb}$ ) } \\
\hline Non-asthmatics & 37.7 & 84.8 & 66.1 & 62.9 & $65(61-69)$ \\
\hline Asthmatics & 87.5 & 52.0 & 82.4 & 61.9 & $82(71-91)$ \\
\hline
\end{tabular}




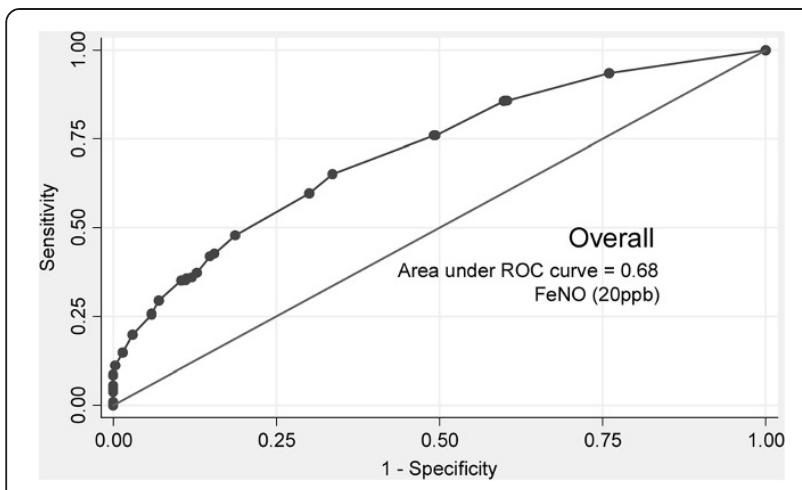

Figure 1 ROC Curve indicating the sensitivity and specificity of Fractional exhaled nitric oxide (FeNO) to predict atopy (FeNO > 20 ppb).

\section{Diagnostic accuracy of FeNO for atopy and asthma}

We evaluated three different cut-off values of FeNO in relation to atopy, and found that $\mathrm{FeNO}>20 \mathrm{ppb}$ was the best predictor for atopy (Table 4). Estimated AUC was $68 \%$ (95\% CI $64 \%$ to $69 \%$ ) after adjusting by sex, BMI, asthma, rhinitis and season of FeNO measurement (Figure 1). We observed better discrimination in specific subgroups. The AUC in non-asthmatics was only $65 \%$ (95\% CI 61\% to 69\%), whereas it increased to $82 \%$ (95\% CI $71 \%$ to $91 \%$ ) in asthmatics (Figure 2). We also found that the AUC was $74 \%$ (95\% CI $65 \%$ to $80 \%$ ) and $66 \%$ (95\% CI $62 \%$ to $70 \%$ ) among those with and without allergic rhinitis, respectively.

We found that there was gradient between the number of positive reactions and the prevalence of atopy. Specifically, mean FeNO for non-atopics was $14.2 \mathrm{ppb}$ $(\mathrm{SD}=13.3)$; $17.0 \mathrm{ppb}$ for atopics with 1 positive reaction $(\mathrm{SD}=15.4) ; 29.2 \mathrm{ppb}(\mathrm{SD}=33.0)$ for atopics with 2 positive reactions; and, $33.9 \mathrm{ppb}(\mathrm{SD}=33.6)$ for atopics with $\geq 3$ positive reactions $(\mathrm{p}<0.001)$. The AUC increased from to $67 \%$ (95\% CI $64 \%$ to $71 \%$ ) to $73 \%$ (95\% CI $70 \%$ to $76 \%$ ) if we considered atopy in participants with $\geq 2$ positive skin tests. Using similar analytical methods, we evaluated the same three FeNO cut-offs in relation to current asthma symptoms, and found that a FeNO $>35$ ppb had a AUC of $80 \%$ (95\% CI $74 \%$ to $85 \%$ ).

\section{Discussion}

Our results suggest that FeNO had a modest ability to identify either atopy alone or asthma alone in our study population; however, our data suggest that it may be a useful aid in differentiating between atopic and nonatopic phenotypes among asthmatic children. We found that a FeNO $>20$ ppb may have sufficient discriminatory power to identify the asthmatic atopic phenotype.

Our results showed that FeNO had limited accuracy in identifying atopy in the general population. These findings contrast with those reported by Yao et al. [17], who reported a better discrimination of FeNO for allergic sensitization in the general population than that reported by our group (AUC of $80 \%, 95 \% \mathrm{CI} 77 \%$ to $82 \%)$. Differences between the study conducted by Yao et al. and our current study could be attributed to the target population and assessment of atopy. Previous studies have described that age contributes to the variability of FeNO $[4,5,8,18,20,25]$. Our study had an older but narrower age range than the study by Yao et al. (5-18 years). Other studies suggest that FeNO may be more useful in young children, who often have no correlation with spirometric assessments or the manifestation of symptoms, but in whom a screening, early diagnosis, and preventive measures would be useful $[19,20]$. Other differences included the method of atopic assessment. Yao et al. conducted atopic assessment using the multi-allergen screen for serum specific IgE (e.g. Phadiatop), whereas we used allergy skin testing. Because allergy skin prick testing does not always identify atopy accurately, measurement of a panel of serum specific IgE is the best method to assess atopy. Some studies report a concordance between 85\% and 95\%, depending on the allergen being tested, between allergy skin testing and measurement of serum specific IgE [29];
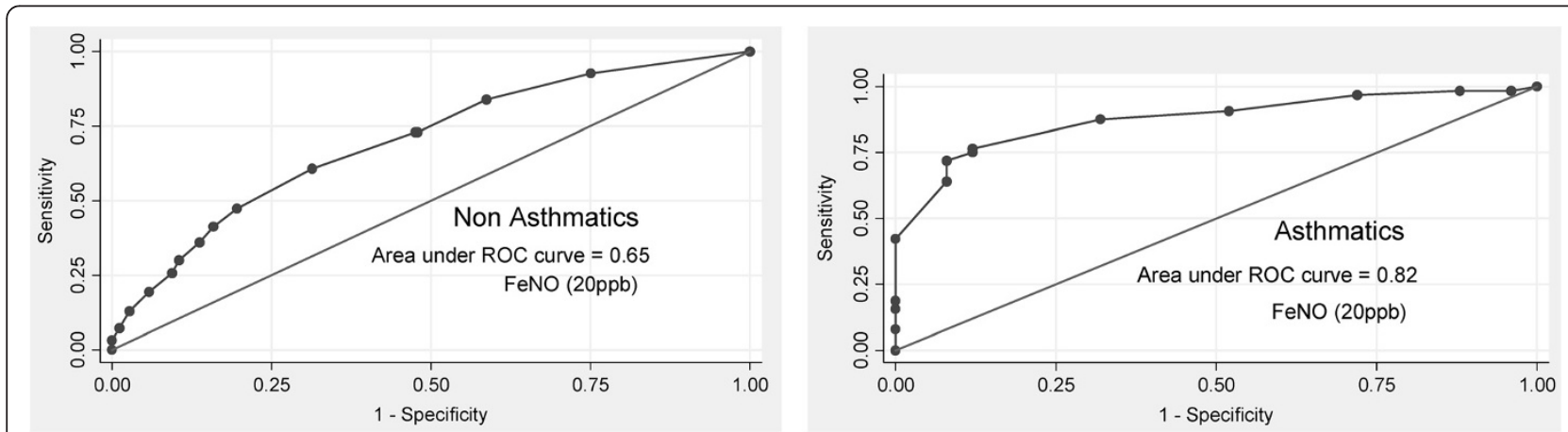

Figure 2 ROC Curve indicating the accuracy of Fractional exhaled nitric oxide (FeNO)measurements to predict atopy by asthma (FeNO > 20ppb). 
however, it is still unclear if these two tests can be used interchangeably to determine atopic sensitization or if both should be used for the diagnosis of atopy [29-31]. Finally, another difference between both studies were that the study by Yao et al. and ours used different chemiluminescence analyzers for FeNO.

Variables such as sex, current asthma, allergic rhinitis, personal history of tobacco use, current use of inhaled corticosteroids, atopy and seasonality have all been previously identified as important explanatory factors that influence FeNO levels [17,20,24,32]. While our study corroborates the importance of these variables in our study setting, we also found that rural dwelling (i.e., living in Tumbes vs. Lima) was additional important explanatory factor associated with FeNO levels. Indeed, few studies have considered the rural versus urban setting in their analysis or study design, despite well-recognized differences in the prevalence of asthma and allergic disease between these two environments $[26,33,34]$. This is particularly relevant to investigations in low- and middle-income countries, as two recent studies conducted in South America, one in Ecuador [33] and another conducted by our team in Peru [26] have shown that urbanization increases the risk of both asthma and allergic diseases. The differences in FeNO levels are explained by the higher prevalence and increased severity of both asthma and atopy in Lima compared to Tumbes [26]. Use of tobacco could impact assessment of FeNO, and if under-reported, could have affected our results. We found an overall low prevalence of daily smokers in previous surveys of tobacco use in our study population. Using a previously-validated, Spanish questionnaires of tobacco smoke in the region, our group reported a low prevalence of daily smoking in adults [35].

Our findings may help to explain previous inconsistences that other studies have reported when using FeNO levels as a criterion in the diagnosis or management of asthma $[6,8,12,15,22,23]$. We found that FeNO $>35$ ppb predicted asthma with better accuracy than cutoffs of $20 \mathrm{ppb}$ or $25 \mathrm{ppb}$. This points to the importance of proper characterization of the atopic phenotype when interpreting the relationship between FeNO and asthma, and also the proper consideration of particular cut-off FeNO values by atopic status, age and sex. Another explanation for previous inconsistences with other studies using FeNO levels could be related to methodology mostly related to flow dependence and the type of device used to measure FeNO. Recently, Malinovschi et al. [36] compared several methods of measuring FeNO and found a better association between asthma control using exhaled breath condensate nitrates rather than with chemiluminescence analyzers for FeNO, which is currently considered the gold standard $[25,36,37]$.
Our study has some potential shortcomings. First, our findings are cross-sectional and we do not evaluate longitudinal changes in FeNO values within individuals. Studies have reported different coefficient of variations from $10 \%$ (about $4 \mathrm{ppb}$ ) in healthy individuals to $40 \%$ in asthmatics [10-12]. Second, we assessed only at a narrow age range, and predictive cut-offs may change with age. Future investigations should include younger children or cover a broad age range, consider within-individual changes in FeNO levels and assessment of environmental allergenic exposures [10,21,25,34,37]. Third, we measured atopic sensitization to indoor aeroallergens only and did not include pollen or food allergens.

We chose not to measure pollens because Lima is located in a semi-arid, tropical region where there are few tree and grass allergens. While it is possible that food allergy may affect our overall prevalence of atopy and potentially the values of fractional exhaled nitric oxide [38]; however, the incidence of food allergies in our study population is unknown and understudied. Fourth, we did not conduct an evaluation of parasitic infections in our study children; however, previous populationbased evaluations by our team on the burden of soilbased helminths in our study areas have been previously found to be low [39]. Finally, another aspect to consider is that potential genetic differences may exist between our study sites, which were settled by different ethnic groups; despite that phenotypically, these populations are similar (i.e., mestizo).

\section{Conclusion}

In summary, our data suggest that FeNO had modest discriminatory power to identify atopy among the general population. It appeared to be a more useful tool to identify atopic phenotype among asthmatics. If this finding is further validated, FeNO may provide a simple, real-time non-invasive screen for atopy among asthmatics especially in resource-poor countries with limited access to medical specialists.

\section{Abbreviations \\ AUC: Area under the curve; PPV: Positive predictive value; NPV: Negative predictive value; $\mathrm{Cl}$ : Confidence intervals; FeNO: Fractional exhaled nitric oxide; ppb: Parts per billion; ROC: Receiver operating characteristic.}

\section{Competing interests}

The authors have no conflicts of interest to disclose.

\section{Authors' contributions}

All authors participated in the study design and conduct, interpretation of findings and writing of manuscript. KR and WC conceived the study hypothesis, were primarily responsible for the analysis plan and writing of the manuscript. CR, LB, RG and $\mathrm{NH}$ were directly involved with study design and conduct. $\mathrm{RH}$ was involved in interpretation of results and provided critically important intellectual content. All authors read and approved the final manuscript. 


\section{Authors' information}

Other PURA study investigators include: Juan Combe MD (A.B. PRISMA, Lima, Peru), Alfonso Gomez MD (A.B. PRISMA, Lima, Peru), Guillermo Gonzalvez MD (PAHO Lima, Peru), Lilia Cabrera RN (A.B. PRISMA, Lima, Peru), Robert Wise (Johns Hopkins University, Baltimore, USA), Kathleen Barnes PhD (Johns Hopkins University, Baltimore, USA), Patrick Breysse PhD (Johns Hopkins University, Baltimore, USA), D’Ann Williams PhD (Johns Hopkins University, Baltimore, USA).

\section{Funding sources}

This study was supported in part by the Johns Hopkins Center for Global Health. Karina Romero was a Fogarty International Center Research Fellow during the conduct of this work (R25TW009340). Nadia Hansel and William Checkley were supported by a R01 grant from the National Institutes of Environmental Health Sciences (R01ES018845). William Checkley was further supported by a Pathway to Independence Award (R00HL096955) from the National Heart, Lung and Blood Institute, National Institutes of Health and by a contract (HHSN268200900033C) with the National Heart, Lung and Blood Institute, National Institutes of Health. Colin Robinson was a Fogarty International Clinical Research Scholar during the time of this work and was further supported by Tufts University School of Medicine. Lauren Baumann was supported by a pre-doctoral NIH T35 Training Grant (T35Al065385). Study sponsors played no role in the study design, data collection, data analysis, data interpretation or the decision to submit the article for publication. Publication of this article was funded in part by the Open Access Promotion Fund of the Johns Hopkins University Libraries.

\section{Author details}

${ }^{1}$ Asociación Benéfica PRISMA, Lima, Peru. ${ }^{2}$ CRONICAS Center of Excellence in Chronic Diseases, Universidad Peruana Cayetano Heredia, Lima, Peru. ${ }^{3}$ Program in Global Disease Epidemiology and Control, Department of International Health, Bloomberg School of Public Health, Johns Hopkins University, Baltimore, USA. ${ }^{4}$ Division of Allergy and Clinical Immunology, School of Medicine, Johns Hopkins University, Baltimore, USA. ${ }^{5}$ Division of Pulmonary and Critical Care, School of Medicine, Johns Hopkins University, 1800 Orleans Street, Suite 9121, Baltimore MD 21205, USA.

Received: 11 February 2013 Accepted: 26 April 2013 Published: 2 May 2013

\section{References}

1. Garcia-Marcos L, Brand P: The utility of sputum eosinophils and exhaled nitric oxide for monitoring asthma control with special attention to childhood asthma. Allergol Immunopathol (Madr) 2010, 38:41-46.

2. Taylor DR, Pijnenburg MW, Smith AD, De Jongste JC: Exhaled nitric oxide measurements: clinical application and interpretation. Thorax 2006, 61:817-827.

3. Barnes PJ, Dweik RA, Gelb AF, Gibson PG, George SC, Grasemann H, Pavord ID, Ratjen F, Silkoff PE, Taylor DR, Zamel N: Exhaled nitric oxide in pulmonary diseases: a comprehensive review. Chest 2010, 138:682-692.

4. Reddel HK, Taylor DR, Bateman ED, Boulet LP, Boushey HA, Busse WW Casale TB, Chanez P, Enright PL, Gibson PG, de Jongste JC, Kerstjens HA, Lazarus SC, Levy ML, O'Byrne PM, Partridge MR, Pavord ID, Sears MR, Sterk PJ, Stoloff SW, Sullivan SD, Szefler SJ, Thomas MD, Wenzel SE, Wenzel SE, American Thoracic Society/European Respiratory Society Task Force on Asthma Control and Exacerbations: An official American thoracic society/ European respiratory society statement: asthma control and exacerbations: standardizing endpoints for clinical asthma trials and clinical practice. Am J Respir Crit Care Med 2009, 180:59-99.

5. Dweick R, Sorkness R, enzel S, Hammel J, Curran-Everett D, Comhair E, Moore W, Peters S, Teague G, Gaston B, Erzurum S: Use of exhaled nitric oxide measurement to identify a reactive, at risk phenotype among patients with asthma. Am J Respir Crit Care Med 2010, 181:1033-1041.

6. Kercsmar C: Exhaled nitric oxide in the diagnosis and management of childhood asthma. Ther Adv Respir Dis 2010, 4:71-82.

7. Brussee JE, Smit HA, Kerkhof M, Koopman LP, Wijga AH, Postma DS, Gerritsen J, Grobbee DE, Brunekreef B, de Jongste JC: Exhaled nitric oxide in 4-year-old children: relationship with asthma and atopy. Eur Respir J 2005, 25:455-461.
8. Cibella F, Cuttitta G, La Grutta S, Passalacqua G, Viegi G: Factors that influence exhaled nitric oxide in Italian schoolchildren. Ann Allergy Asthma Immunol 2008, 101:407-412.

9. Sivan $Y$, Gadish T, Fireman E, Soferman R: The use of exhaled nitric oxide in the diagnosis of asthma in school children. J Pediatr 2009, 155:211-216.

10. Szefler S, Wenzel S, Brown R, Erzurum S, Fahy J, Minnicozzi M, et al: Asthma outcomes: Biomarkers. J Allergy Clin Immunol 2012, 129:S9-23.

11. Ekroos H, Rouhos A, Pallasaho P, Karjalainen J, Sarna S, Sovijärvi ARA: Equally elevated concentrations of exhaled nitric oxide in nonatopic and low-sensitized atopic asthmatics. Respir Med 2009, 103:152-158.

12. Banovcin P, Jesenak M, Michnova Z, Babusikova E, Nosal S, Mikler J, Fabry J, Barreto M: Factors attributable to the level of exhaled nitric oxide in asthmatic children. Eur J Med Res 2009, 14:9-13.

13. Robinson $\mathrm{CL}$, Baumann LM, Romero K, Combe JM, Gomez A, Gilman RH, Cabrera L, Gonzalvez G, Hansel NN, Wise RA, Barnes KC, Breysse PN, Checkley W: Effect of urbanisation on asthma, allergy and airways inflammation in a developing country setting. Thorax 2011, 66:1051-57.

14. Nadif R, Matran R, Maccario J, Bechet M, Le Moual N, Scheinmann P, Bousquet J, Kauffmann F, Pin I: Passive and active smoking and exhaled nitric oxide levels according to asthma and atopy in adults. Ann Allergy Asthma Immunol 2010, 104:385-393.

15. Berg CM, Thelle DS, Rosengren A, Lissner L, Toren K, Olin AC: Decreased fraction of exhaled nitric oxide in obese subjects with asthma symptoms: data from the population study INTERGENE/ADONIX. Chest 2010, 139:1109-1116.

16. Johansson SG, Bieber T, Dahl R, Friedmann PS, Lanier BQ, Motala C, Ortega Martell JA, Platts-Mills TA, Ring J, Thien F, Van Cauwenberge P, Williams HC Revised nomenclature for allergy for global use: report of the nomenclature review committee of the world allergy organization, October 2003. J Allergy Clin Immunol 2004, 113:832-836.

17. Yao TC, Ou LS, Lee WI, Yeh KW, Chen LC, Huang JL, PATCH study group: Exhaled nitric oxide discriminates children with and without allergic sensitization in a population-based study. Clin Exp Allergy 2011, 41:556-564.

18. Scott M, Raza A, Karmaus W, Mitchell F, Grundy J, Kurukulaaratchy RJ, Arshad SH, Roberts G: Influence of atopy and asthma on exhaled nitric oxide in an unselected birth cohort study. Thorax 2010, 65:258-262.

19. Jackson D, Virnig C, Gangnon R, Evans M, Roberg K, Anderson E, Burtoon R, Salazar L, Da Sllva D, Shanovich K, Tisler C, Gern J, Lemanske R: Fractional exhaled Nitric Oxide (FeNO) measurements are most closely associated with allergic sensitization in school aged children. J Allergy Clin Immunol 2009, 124:949-953.

20. Baena-Cagnani CE, Badellino HA: Diagnosis of allergy and asthma in childhood. Curr Allergy Asthma Rep 2010, 11:71-77.

21. Bousquet J, Heinzerling L, Bachert C, Papadopoulos N, Bousquet J, Burney P, Demoly $P$ : Practical guide to skin prick tests in allergy to aeroallergens. Allergy 2011, 67:18-24.

22. Taylor DR: Exhaled nitric oxide: still alive, not laid to rest. Am J Respir Crit Care Med 2009, 179:88-89.

23. Rouhos A, Kainu A, Karjalainen J, Lindqvist A, Piirilä P, Sarna S, Haahtela T, Sovijärvi AR: Atopic sensitization to common allergens without symptoms or signs of airway disorders does not increase exhaled nitric oxide. Clin Respir J 2008, 2:141-8.

24. Spanier AJ, Hornung RW, Kahn RS, Lierl MB, Lanphear BP: Seasonal variation and environmental predictors of exhaled nitric oxide in children with asthma. Pediatr Pulmonol 2008, 43:576-83.

25. Dweik R, Boggs P, Erzurum S, Irvin C, Leigh M, Lundberg J, Olin A, Plummer A, Taylor D: An official ATS clinical practice guideline: interpretation of exhaled nitric oxide levels (FeNO) for clinical applications. Am J Respir Crit Care Med 2011, 184:602-15.

26. Robinson CL, Baumann LM, Gilman RH, Romero K, Combe JM, Cabrera L, Hansel NN, Barnes K, Gonzalvez G, Wise RA, Breysse PN, Checkley W: The Peru Urban versus Rural Asthma (PURA) Study: methods and baseline quality control data from a cross-sectional investigation into the prevalence, severity, genetics, immunology and environmental factors affecting asthma in adolescence in Peru. BMJ Open 2012, 2:e000421.

27. WHO Reference: Growth reference data for 5-19 years. 2007. URL: http:// www.who.int/growthref/who2007_bmi_for_age/en/index.html.

28. Arlot S, Celisse A: A survey of cross-validation procedures for model selection. Statist Surv 2010, 4:40-79. 
29. Heinzerling L, Mari A, Bergmann K, Bresciani M, Burbach G, Darsow 2013, Durham S, Fokkens W, Gjomarkaj M, Haahtela T, Bom A, Wöhrl S, Maibach H, Lockey R: The skin prick test - European standards. Clin Trans/ Allergy 2013, 3:3.

30. Ro A, Saunes M, smidsang I, Storno O, Oien T, Moen T: Agreement of specific lgE and skin prick test in an unselected cohort of 2 years old children. Eur J Pediatr 2011, 11:1580-89.

31. Mehl A, Niggemann B, Keil T, Wahn U, Beyer K: Skin prick test and specific serum IgE in the diagnostic evaluation of suspected cow's milk and hen's egg allergy in children: does one replace the other? Clin Exp Allergy 2012, 42:1266-72.

32. Kostikas K, Papaioannou A, Tanou K, Koutsokera A, Papala M, Gourgoulianis $K$ : Portable exhaled nitric oxide as a screening tool for asthma in young adults during pollen season. Chest 2008, 133:906-913.

33. Rodriguez A, Vaca M, Oviedo G, Erazo S, Chico ME, Teles C, Barreto ML, Rodrigues LC, Cooper PJ: Urbanisation is associated with prevalence of childhood asthma in diverse, small rural communities in Ecuador. Thorax 2011, 66:1043-1050.

34. Asher I: Urbanization, asthma and allergies. Thorax 2011, 66:1025-1026.

35. Weygandt PL, Vidal-Cardenas E, Gilman RH, Avila-Tang E, Cabrera L, Checkley W: Epidemiology of tobacco use and dependence in adults in a poor peri-urban community in Lima, Peru. BMC Pulm Med 2012, 12(9):2466-9.

36. Malinovschi A, Pizzimenti S, Sciascia S, Heffler E, Badiu I, Rolla G: Exhaled breath condensate nitrates, but not nitrites or FFENO, relate to asthma control. Respir Med 2011, 105:1007-13.

37. Spanier AJ, Kahn RS, Hornung RW, Wang N, Sun G, Lierl MB, Lanphear BP: Environmental exposures, nitric oxide synthase genes, and exhaled nitric oxide in asthmatic children. Pediatr Pulmonol 2009, 44:812-9.

38. Kulkarni N, Ragazzo V, Costella S, Piacentini G, Boner A, O'Callaghan C, Fiocchi A, Kantar A: Eosinophilic airway inflammation is increased in children with asthma and food allergies. Pediatr Allergy Immunol 2012, 23:28-33.

39. Checkley W, Robinson CL, Baumann LM, Romero K, Combe JM, Gilman RH, Wise RA, Hamilton RG, Gonzalvez G, Cama V, Hansel NN, PURA study investigators: Effect of urbanization on the relation of total serum immunoglobulin E to asthma. Eur Respir J 2013; 41:1074-81.

doi:10.1186/1465-9921-14-48

Cite this article as: Romero et al: Role of exhaled nitric oxide as a predictor of atopy. Respiratory Research 2013 14:48.

\section{Submit your next manuscript to BioMed Central and take full advantage of:}

- Convenient online submission

- Thorough peer review

- No space constraints or color figure charges

- Immediate publication on acceptance

- Inclusion in PubMed, CAS, Scopus and Google Scholar

- Research which is freely available for redistribution 